\title{
CONTENTS OF OTHER JOURNALS FROM THE REGION SZOCIOLÓGIAI SZEMLE
}

http://www.szociologia.hu/2017_2_szam/ Issue No. 2. 2017

Németh Krisztina, Beszédes hallgatás. A csend interpretálása és a megismerés dilemmái a társadalomtudományi kutatásban; Zombory Máté, A tanú elhallgattatása és a történelem visszatérése. A kulturális traumaelmélet kudarca; Vigvári András, Kettős kihívás előtt. A hallgatás megtörése és a megosztás felelössége a kortárs terepkutatásokban; Virág Tünde, A közösségi narratíva szerepe az eltakart valóság megismerésében; Katona Noémi, Szégyen és hallgatás. A kutató szerepe a prostitúció elbeszélésében; Durst Judit, „De ugye biztos nem lesz ebből baj?": Posztterepmunka, kooperatív etnográfia, avagy módszertani reflexiók az informális gazdaságot övező félelem csendjének megtöréséröl

\section{SOCIO.HU}

Turai Tünde, Beilleszkedés és kiilleszkedés, otthon és otthontalanság. A társadalmi beágyazottság újraszerveződése a kelet- és közép-európai házi ápolók migráns életútjában; Durst Judit - Fehér Katalin - Németh Krisztina - Váradi Monika Mária - Virág Tünde, Kényszerü mobilitás: migrációs utak hátrányos helyzetű vidéki terekben; Hamar Anna, Romániai vándormunkások és áttelepültek a kertészeti idénymunka piacán; Takács Judit - P. Tóth Tamás, Megbélyegzett kapcsolatok az államszocialista Magyarországon 


\section{SOCIETY AND ECONOMY}

http://www.akademiai.com/toc/204/current Issue No. 4. 2017

Attila Tasnádi - Balázs Szent-Iványi, Editorial; Maria Csutora - Gabor Harangozo, Twenty years of carbon accounting and auditing - a review and outlook; Tereza De Castro Jana Vlčková Pavel Hnát, Trade and investment relations between the Czech Republic and China: The Czech Republic as a gateway to the EU?; Miklós Lukovics Erik Fisher, Socio-technical integration research in an Eastern European setting: Distinct features, challenges and opportunities; Daniel Gugan, Europe and its southern neighbors. Interdependence, security and economic development in contemporary EU-MENA relations; Ilona Miklós, The apricot story: Patterns in a local circular food chain in North Hungary; Eszter Kovács Erika Gulyás Tamás Sterbenz, Determinants of a nation's sport performance at different mega sport events; Anna S. Gogoleva Pavel S. Sorokin Azer G. Efendiev, Problems and perspectives in research into the quality of work life in organisational studies; László Trautmann, Jody Jensen and Ferenc Miszlivetz (eds.) Reframing Europe's Future: Challenges and Failures of the European Construction

\section{INTERSECTIONS. EAST-EUROPEAN JOURNAL OF SOCIETY AND POLITICS}

http://intersections.tk.mta.hu/index.php/intersections Issue No.3. 2017

Manuela Caiani, Between Contextual Opportunities and Discursive Resources; Márton Gerő, Piotr P. Płucienniczak, Alena Kluknavska, Jiří Navrátil, Kostas Kanellopoulos,Understanding Enemy Images in Central and Eastern European Politics; Milan Hrubeš, Jiř́i Navrátil, Constructing a Political Enemy; Dániel Kovarek, Dániel Róna, Bulcsú Hunyadi, Peter Kreko, Scapegoat-Based Policy Making in Hungary; Justyna Kajta, Discursive Strategies of Polish Nationalists in the Construction of the Other; Ákos Kopper, Pál Susánszky, Gergely Tóth, Márton Gerö, Creating Suspicion and Vigilance; Luca Kristóf, Cultural Policy in an Illiberal State 


\section{POLISH SOCIOLOGICAL REVIEW}

http://polish-sociological-review.eu/

Issue No. 3. 2017

Jacek Bieliński, Political Legitimacy and Normative Disorientation in European Liberal Democracies; Rafał Riedel, Populism and Its Democratic, NonDemocratic, and Anti-Democratic Potential; Henryk Domański, Omnivorism of Eating and 'Highbrow-Lowbrow' Distinction: Cultural Stratification in Poland; Luís Cordeiro Rodrigues - Emanuele Achino, A Case Study on Moral Disengagement and Rationalization in the Context of Portuguese Bullfighting; Aleksandra Wilczyńska - Dominik Batorski - Joan Torrent-Sellens, Job Satisfaction of Knowledge Workers. The Role of Interpersonal Justice and Flexible Employment; Tatiana Kanasz - Iwona Zielińska, Emotional Labour of the Polish Social Workers: The Study in Sociology of Emotions; Łukasz Krzyżowski - Krystyna Slany - Magdalena Ślusarczyk, Care Issues in the Transnational Families. A Polish Research Review; Jolita Viluckiene - Jonas Ruškus, Configurations of Using Social Networking Sites and Perceived Online Social Capital Among Adults With and Without Disabilities

\section{SOCIOLOGICKÝ ČASOPIS / CZECH SOCIOLOGICAL REVIEW}

http://sreview.soc.cas.cz/en/issue/current Issue No. 5. 2017

Ivana Přidalová, Martin Ouředníček, The Role of Foreign Migration in the Changing Socio-Spatial Differentiation of Prague; Tomáš Doseděl, Tomáš Katrňák, Economic and Non-economic Returns to Higher Education during a Period of Educational Expansion in the Czech Republic; Marcela Petrová Kafková, Tatiana Sedláková, The Fourth Age as a Specific Field for the Expression of Agency; Zdeněk R. Nešpor, 'If You Leave Me, You Will Die...' The Academic Trajectories of Otakar Machotka and other Émigré Czech Sociologists after February 1948; Marek Skovajsa, Sociologie v Rakousku: spletitý př́iběh s dobrým koncem; Jan Maršálek, Jan Keller: Evropské rozpory ve světle migrace; Tomáš Doseděl, Eliška Hudcová, Pavel Pospěch a kol.: Vynalézání venkova v ČR po roce 1989; Marek Mikuš; Ondřej Horký-Hlucháň, Tomáš Profant a kol.: Mimo Sever a Jih. Rozumět globálním nerovnostem a rozmanitosti; Jiří Podhajský, Erazim Kohák: Oheň a hvězdy. Filosofická zamýšlení nad morálním smyslem př́rody 


\section{SOCIOLÓGIA - SLOVAK SOCIOLOGICAL REVIEW}

http://www.sav.sk/index.php?lang=en\&doc=journal-list\&journal_no=36

Issue No. $\overline{5} \cdot 2017$

Hrubá, L., Social Determinants of High Parental Educational Expectations; Kopřiva, R. - Čopík, J. - Čmejrek, J., Decision-Making Mechanisms on Investment Aims and Budgets of Municipalities; Kusá, Z., Beyond Solidarity Boundaries. Defending the Principle of Dignity for All; Svoboda, A.. The Concept of Subcultures in the Sociology of Sport; Šprocha, B. - Št’astná, A. - Š́́dlo, L., Childlessness - a New Phenomenon in the Life Courses of Women in Slovakia

\section{REVIJA ZA SOCIOLOGIJU}

https://hrcak.srce.hr/index.php?show=toc\&id_broj=15158

Issue No.2. 2017

Alistair Ross, Saša Puzić, Karin Doolan, Balkan and European? Place Identifications of Young People in Croatia; Tibor Rutar, Clarifying Power, Domination, and Exploitation: Between "Classical" and "Foucauldian" Concepts of Power; Davorka Matić, The Calling of Sociology: Beyond Value-detached Professionalism and Partisan Activism; Majda Hrženjak, A Qualitative Study of Labour Market Precarisation and Involved Fatherhood in Slovenia

\section{SOCIOLOGIJA. ČASOPIS ZA SOCIOLOGIJU, SOCIJALNU PSIHOLOGIJU I SOCIJALNU ANTROPOLOGIJU}

http://www.sociologija.org/books/issues.php?lng=english Issue No.3. 2017

Dušan Marinković, Dušan Ristić, Genealogy of The Transformations of Class Strategies: To See, To Speak, To Know; Todor Kuljić, Historical concepts: a connection of an analytical and creative aspect; Božidar Filipović. Rat i zločin kao izvori moralne obnove i jedinstva - republikansko nasleđe i njegova transformacija u delu Emila Dirkema; Nemanja Kostić, The use of St. Sava in setting ethnoreligious boundaries: sociological-historical approach Mladen Radulović - Sabina Autor - Dragana Gundogan, Parental Education and Educational Aspirations of Children: Cases of Serbia and Slovenia; Nataša 
Krstić, The implementation of Children's Rights and Business Principles in the corporate social responsibility strategy of Serbian enterprises; Dragica Krsmanović - Dragana Radisavljević Ćiparizović, Scientific bibliography of prof. Sreten Vujovic for 1968-2016 period

\section{TEORIJA IN PRAKSA}

http://www.fdv.uni-lj.si/en/journals/science-journals/teorija-in-praksa Issue No.5 2017

Rok Čeferin - Melita Poler, Journalistic Code of Ethics and Journalists' Liability For Damages: Analysis of the Case Law of the Supreme Court of the Republic of Slovenia; Tanja Kamin - Jernej Berzelak - Mirjana Ule, Mind the Gap: Social Aspects of Willingness for Post-Mortem Organ Donation in Slovenia; Filip Kokotović - Petar Kurečić, An Empirical Analysis of Voting Patterns in Four Battleground States of the 2016 US Presidential Election; Mojca Jakačić - Slavko Kurdija, Analysis of Undecided Voters and the Question of Voter Turnout in the Case of Local Elections in Ljubljana; Dario Berginc: Strategic Factors Affecting Decision-Making in Firms; Drago Kos, Editorial; Drago Kos - Samo Pavlin: The Long-Term Development of Educational Programmes: The Case of The Slovenian Gymnasium; Marjan Hočevar, Conceptual Framework for Sustainable Mobility Structuration in the Circumstances of Supranational Integration; Simona Zavratnik - Rebeka Falle Zorman - Živa Broder, Public Opinion and Migrations: Mechanisms of Classifications and the Refugee Crisis; Matjaž Uršič - Samo Pavlin - Primož Medeved, Occupational Development in the Field of Sustainable Urbanism - The Case of Sustainable Neighbourhoods

\section{EUROPEAN QUARTERLY OF POLITICAL ATTITUDES AND MENTALITIES}

https://sites.google.com/a/fspub.unibuc.ro/european-quarterly-of-political-attitudes-and-mentalities/ Issue No. 42017

Dobrinka Peicheva and Lilia Rayceva, Framing Political Populism in Contemporary Media Ecosystem; Camelia Florela Voinea, On the Elites in the Eastern European Post-communist Countries. Political Elites in the Eastern European Political Regimes After the Fall of the Berlin Wall:An Interdisciplinary Methodological Approach 
